\title{
PENERAPAN MODEL PEMBELAJARAN INKUIRI TERBIMBING PADA MATERI SEGIEMPAT DAN SEGITIGA TERHADAP PEMAHAMAN KONSEP MATEMATIKA DI SMP ISLAM SOERJO ALAM
}

\author{
Enny Ristanty ${ }^{1}$, Riski Nur Istiqomah Dinnullah ${ }^{2}$, Nur Farida ${ }^{3}$ \\ ${ }^{1}$ Program Studi Pendidikan Matematika, Universitas Kanjuruhan Malang \\ ennyristanty905@gmail.com \\ ${ }^{2}$ Program Studi Pendidikan Matematika, Universitas Kanjuruhan Malang \\ ky2_zahra@unikama.ac.id \\ ${ }^{3}$ Program Studi Pendidikan Matematika, Universitas Kanjuruhan Malang \\ nurfarida@unikama.ac.id
}

\begin{abstract}
Abstrak: Penelitian ini bertujuan untuk mendeskripsikan penerapan model pembelajaran inkuiri terbimbing pada materi segiempat dan segitiga terhadap pemahaman konsep matematika. Penelitian ini merupakan Penelitian Tindakan Kelas. Penelitian ini dilaksanakan dalam dua siklus, tiap siklus terdiri dari dua pertemuan. Setiap siklus terdapat 4 tahapan, yaitu mulai dari perencanaan, pelaksanaan, pengamatan, dan refleksi. Subjek penelitian adalah 33 peserta didik kelas VII SMP ISLAM SOERJO ALAM. Data penelitian diperoleh dari observasi, tes, wawancara, dan catatan lapangan. Berdasarkan hasil penelitian dapat disimpulkan bahwa pembelajaran matematika dengan menggunakan model pembelajaran inkuiri terbimbing pada materi segiempat dan segitiga dapat: (1) meningkatkan kemampuan pemahaman konsep matematika peserta didik yaitu sebelum dilaksanakan tindakan nilai ratarata peserta didik sebesar 56,3 dengan ketuntasan klasikal sebesar 12,12\%, setelah dilaksanakan tindakan nilai rata-rata peserta didik meningkat menjadi 78,6 dengan ketuntasan klasikal sebesar $72,72 \%$ pada Siklus I, dan nilai rata-rata peserta didik meningkat menjadi 86,9 dengan ketuntasan klasikal sebesar 93,93\% pada Siklus II dan (2) keterlaksanaan pembelajaran dilihat dari kegiatan guru sebesar 90\% (kategori baik), kegiatan peserta didik sebesar $85 \%$ (kategori baik) pada Siklus I dan pada Siklus II keterlaksanaan pembelajaran dilihat dari kegiatan guru meningkat menjadi $96,25 \%$ (kategori baik), kegiatan peserta didik menjadi 93,75\% (kategori baik).
\end{abstract}

Kata Kunci: Model Pembelajaran Inkuiri Terbimbing, Pemahaman Konsep Matematika, Segiempat dan Segitiga

\section{Pendahuluan}

Pembelajaran matematika di sekolah tidak bisa terlepas dari sifat-sifat matematika yang abstrak (Rostina, 2013:2). Matematika yang bersifat abstrak menyebabkan kesulitan tersendiri yang harus dihadapi oleh peserta didik. Selain itu, peserta didik menganggap matematika sukar dipahami dan menjadi momok yang menakutkan. Ketakutan peserta didik terhadap matematika membuat peserta didik tidak dapat memahami konsep-konsep yang terdapat pada matematika. Sementara itu, pemahaman konsep yang terdapat dalam matematika sangat diperlukan untuk memahami matematika. Konsep dasar pada matematika harus benar-benar dikuasai sejak awal sebelum mempelajari matematika lebih lanjut. Jika peserta didik telah memahami konsep terlebih dahulu, maka akan memudahkan peserta didik dalam menerima materi selanjutnya. Oleh karena itu, seorang guru perlu memperhatikan sifat pembelajaran matematika di sekolah dan harus menanamkan konsep matematika dengan baik agar peserta didik dapat 
membangun nalarnya secara logis, sistematis, konsisten, kritis, dan disiplin.

Menurut Dian (2014:5) untuk memahamkan peserta didik dalam pembelajaran matematika perlu adanya langkah-langkah penanaman konsep dasar, pemahaman konsep atau pembelajaran lanjutan dari penanaman konsep yang bertujuan agar peserta didik lebih memahami konsep matematika, dan juga pembinaan keterampilan. Wardhani (2008:10) berpendapat bahwa kemampuan pemahaman konsep matematika meliputi: menyatakan ulang sebuah konsep, mengklasifikasi objek menurut sifat-sifat tertentu sesuai dengan konsepnya, memberi contoh dan dan bukan contoh dari suatu konsep, menyajikan konsep dalam berbagai bentuk representasi matematis, mengembangkan syarat perlu atau syarat cukup dari suatu konsep, menggunakan dan memanfaatkan serta memilih prosedur atau operasi tertentu, dan mengaplikasikan konsep atau logaritma pada pemecahan masalah.

Berdasarkan pengamatan yang dilakukan pada pembelajaran matematika di SMP ISLAM SOERJO ALAM di kelas VII, peneliti menemukan beberapa permasalahan dalam proses pembelajaran. Pembelajaran matematika di kelas VII masih berpusat pada guru sementara peserta didik cenderung pasif. Sebagian peserta didik kurang memahami konsep pembelajaran dan hanya memahami contoh soal serta penyelesaiannya sehingga pemahaman konsep matematika peserta didik menjadi tidak seperti yang diharapkan. Berdasarkan wawancara dengan guru matematika mengatakan bahwa masih banyak peserta didik yang mendapat nilai di bawah KKM. Guru berpendapat bahwa banyaknya peserta didik yang mendapat nilai di bawah 75 disebabkan oleh beberapa faktor yang salah satunya adalah pemahaman konsep peserta didik masih kurang.

Pada saat pengamatan di sekolah, peserta didik diberikan soal cerita terkait materi segiempat dan segitiga. Sebagai contoh, sebuah taman berbentuk persegi panjang berukuran $9 \mathrm{~m} \times 6 \mathrm{~m}$. Jika di sekeliling taman tersebut dipasang tiang lampu dengan jarak antar tiang $3 \mathrm{~m}$, berapa banyak tiang lampu yang dibutuhkan. Dari hasil pekerjaan peserta didik nampak bahwa peserta didik masih bingung dalam menentukan penggunaan rumus mana yang akan digunakan. Berdasarkan analisis hasil tes pemahaman konsep matematika pra siklus kelas VII, kemampuan pemahaman konsep matematika peserta didik masih rendah.

Dalam permasalahan seperti di atas, guru perlu memahamkan konsep dari penanaman konsep yang telah diketahui peserta didik sebelumnya. Selain itu, dalam proses pembelajaran guru harus memiliki strategi agar peserta didik dapat belajar secara efektif dan efisien serta mengena pada tujuan yang diharapkan. Salah satu langkahnya adalah guru harus menggunakan model pembelajaran yang tepat, karena dengan penggunaan model pembelajaran yang tidak sesuai akan mempengaruhi peserta didik dalam menerima pelajaran (Watu, 2016:8). Maka dari itu, dibutuhkan suatu model pembelajaran yang dapat membantu peserta didik agar dapat memahami konsep dasar suatu materi pelajaran yaitu dengan menggunakan model pembelajaran inkuiri terbimbing.

Menurut Gulo (2008:11) model pembelajaran inkuiri terbimbing adalah suatu rangkaian kegiatan belajar yang melibatkan secara maksimal seluruh kemampuan peserta didik untuk mencari dan menyelidiki secara sistematis, kritis, logis, dan analitis, sehingga peserta didik dapat merumuskan sendiri penemuannya 
dengan penuh percaya diri. Selain itu, model inkuiri terbimbing juga lebih menekankan pada aktivitas peserta didik, peserta didik mencari dan menemukan jawaban sendiri di bawah bimbingan guru sehingga diharapkan mampu meningkatkan pemahaman konsep matematika peserta didik. Dengan kata lain model pembelajaran inkuiri terbimbing tidak lagi berpusat pada guru tetapi pada pengembangan nalar kritis peserta didik. Selain itu, peserta didik tidak akan lagi berada dalam ruang lingkup pembelajaran telling science akan tetapi didorong hingga bisa doing science.

Pembelajaran matematika dengan menggunakan model inkuiri terbimbing memberikan ruang sebebas-bebasnya bagi peserta didik untuk menemukan cara belajarnya masing-masing. Nilai positifnya, peserta didik tidak hanya akan mengetahui tetapi juga memahami intisari dan potensi-potensi pengembangan atas materi matematika yang diajarkan. Jadi, dalam konteks ini guru tidak lagi menjadi penentu arah haluan pembelajaran, akan tetapi guru harus mampu menghidupkan semangat dan motivasi belajar sehingga peserta didik dapat menikmati proses belajar tersebut.

Model pembelajaran inkuiri terbimbing dapat membentuk dan mengembangkan self concept pada diri peserta didik sehingga peserta didik dapat mengerti tentang konsep dan ide-ide lebih baik (Anam, 2016:15-16). Adapun langkah-langkah model pembelajaran inkuiri terbimbing antara lain: merumuskan masalah, merumuskan jawaban sementara, menguji jawaban alternatif, menarik kesimpulan, dan menerapkan kesimpulan serta generalisasi. Tujuan dari penelitian ini adalah untuk mendeskripsikan penerapan model pembelajaran inkuiri terbimbing pada materi segiempat dan segitiga terhadap pemahaman konsep matematika di SMP ISLAM SOERJO ALAM.

\section{Metode Penelitian}

Pendekatan yang digunakan adalah pendekatan penelitian kualitatif, sedangkan jenis penelitian yang digunakan adalah penelitian tindakan kelas. Penelitian ini dilaksanakan di SMP ISLAM SOERJO ALAM pada tahun ajaran 2016/2017 semester genap. Subjek dalam penelitian ini adalah 33 peserta didik kelas VII. Untuk objek dalam penelitian ini adalah penerapan model pembelajaran inkuiri terbimbing pada materi segiempat dan segitiga. Teknik pengumpulan data dalam penelitian ini melalui pengamatan, pemberian tes, wawancara, pengisian catatan lapangan, dan dokumentasi. Teknik analisis data pada penelitian ini menggunakan dua metode yaitu metode kualitatif dan kuantitatif. Analisis data kualitatif digunakan untuk peningkatan proses belajar, sedangkan analisis data kuantitatif digunakan untuk menentukan pemahaman konsep matematika peserta didik. Tahapan dalam penelitian ini menggunakan model Kurt Lewin (dalam Kusumah, 2012:44) yang terdiri dari empat tahapan yaitu: (1) perencanaan, (2) pelaksanaan, (3) pengamatan, dan (4) refleksi. Empat tahapan tersebut disebut sebagai satu siklus. Tahap-tahap tersebut dapat digambarkan sebagai berikut: 


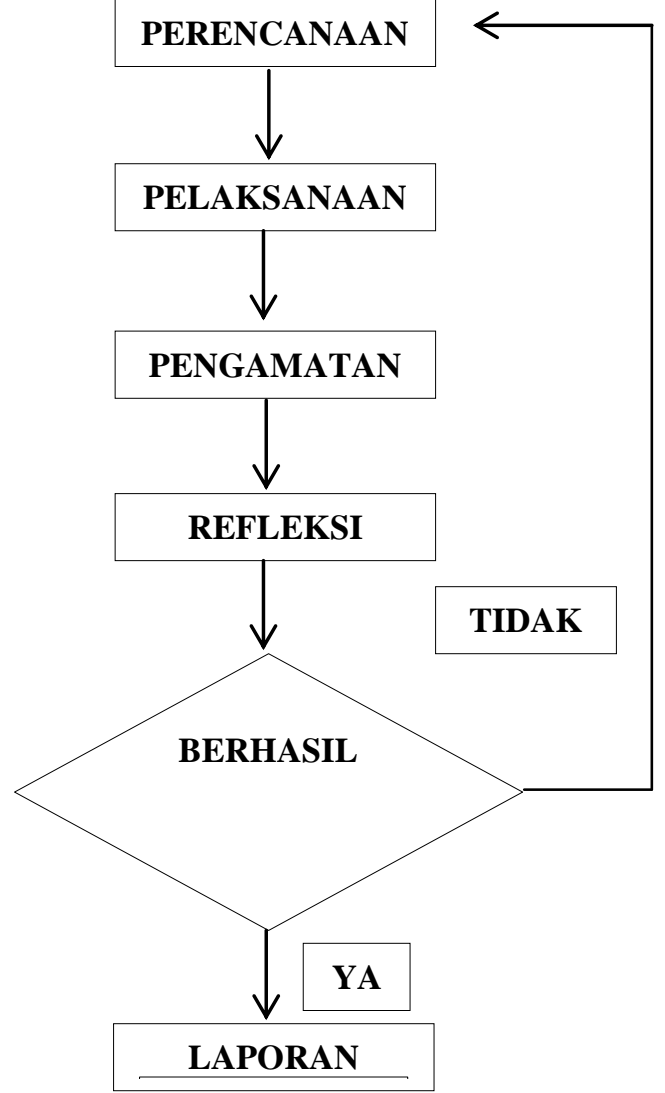

Gambar 1. Tahap-tahap Penelitian

Penelitian ini dirancang dalam dua siklus dimana setiap siklus terdiri dari dua pertemuan. Adapun rincian dari tahap-tahap yang ditempuh pada penelitian ini adalah sebagai berikut:

1. Tahap perencanaan

a. Menyiapkan RPP (Rencana Pelaksanaan Pembelajaran).

b. Mempersiapkan bahan ajar.

c. Menyiapkan LKK (Lembar Kerja Kelompok).

d. Menyiapkan alat evaluasi untuk melihat tingkat pemahaman konsep matematika peserta didik.

e. Menyiapkan lembar observasi aktivitas guru dan peserta didik, lembar wawancara, dan lembar catatan lapangan.

2. Tahap pelaksanaan

a. Guru melakukan pembelajaran dengan menggunakan model pembelajaran inkuiri terbimbing yang sesuai tahap di RPP. b. Guru melakukan kegiatan tes akhir siklus untuk mengetahui tingkat pemahaman konsep matematika peserta didik.

c. Peserta didik mengikuti pembelajaran dan melaksanakan kegiatan sesuai dengan petunjuk dari guru.

3. Tahap pengamatan

a. Observer melakukan pengamatan terkait dengan aktivitas guru dan peserta didik.

b. Guru melakukan pengamatan terkait hasil tes peserta didik.

4. Tahap refleksi

Tahap refleksi dilakukan untuk melihat secara keseluruhan proses pembelajaran yang dilakukan dan hasil pemahaman konsep matematika peserta didik. Apabila pada siklus yang telah dilakukan berhasil maka dilanjutkan ke tahap pembuatan laporan akan tetapi jika tidak berhasil maka peneliti mengulang kembali dengan memperbaiki kekurangan yang ada pada siklus sebelumnya.

\section{Hasil dan Pembahasan}

Hasil keterlaksanaan pembelajaran diperoleh dari hasil observasi aktivitas guru dan peserta didik serta catatan lapangan selama pembelajaran berlangsung. Observer melakukan pengamatan sesuai dengan petunjuk pada lembar observasi dan mengisi lembar tersebut dengan memberikan tanda centang pada kolom yang telah dipilih. Data hasil observasi dianalis menggunakan analisis persentase. Sementara untuk pengisian catatan lapangan digunakan untuk melengkapi data yang tidak termuat pada lembar observasi.

Pada Siklus I persentase nilai ratarata observasi aktivitas guru (peneliti) adalah 90\% sedangkan persentase nilai rata-rata observasi aktivitas peserta didik 
adalah $85 \%$. Sementara pada Siklus II persentase nilai rata-rata observasi aktivitas guru (peneliti) sebesar 96,25\% sedangkan persentase nilai rata-rata observasi aktivitas peserta didik sebesar 93,75\%. Hasil ini menunjukkan bahwa keterlaksanaan pembelajaran dengan menggunakan model inkuiri terbimbing mengalami peningkatan. Adapun grafik peningkatan keterlaksanaan pembelajaran adalah sebagai berikut:

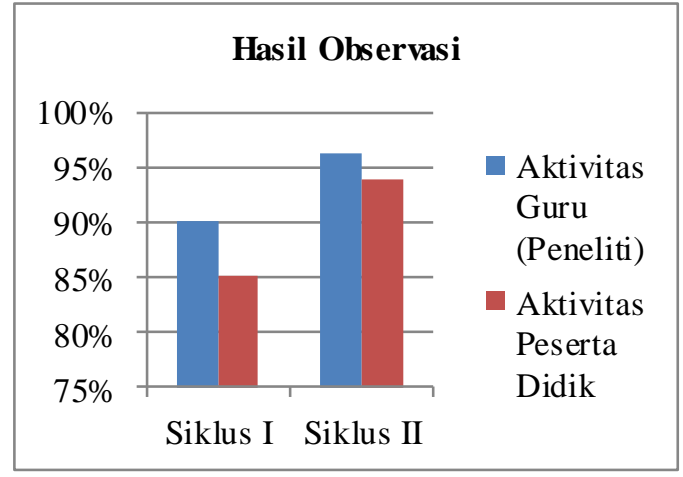

Gambar 2. Grafik Keterlaksanaan

Pembelajaran Berdasarkan Hasil Observasi dari Siklus I ke Siklus II

Dari gambar di atas, dapat dikatakan bahwa proses pembelajaran dengan menggunakan model inkuiri terbimbing dapat terlaksana dengan baik dikarenakan telah mendapat skor lebih dari $75 \%$.

Setelah melaksanakan tindakan pembelajaran pada Siklus I dan Siklus II, peserta didik diberikan tes di setiap akhir siklus untuk mengetahui tingkat pemahaman konsep matematika peserta didik. Hasil tes akhir siklus diolah dengan mencari rata-ratanya kemudian membandingkan dengan nilai rata-rata awal peserta didik dan mencari ketuntasan klasikalnya. Pemahaman konsep matematika peserta didik dikatakan berhasil apabila sudah mencapai kriteria ketuntasan klasikal lebih dari $75 \%$.

Pada tes awal yang diberikan sebelum tindakan diperoleh nilai rata-rata kemampuan pemahaman konsep matematika peserta didik kelas VII adalah 56,3 dengan ketuntasan klasikal sebesar $12,12 \%$ dengan 4 peserta didik yang mencapai ketuntasan. Pada Siklus I diperoleh nilai rata-rata tes pemahaman konsep matematika sebesar 78,6 dengan ketuntasan klasikal sebesar 72,72\% dengan 24 peserta didik yang mencapai ketuntasan. Nilai rata-rata kemampuan pemahaman konsep peserta didik sudah meningkat, akan tetapi ketuntasan klasikal yang diperoleh peserta didik masih belum terpenuhi, maka dilakukan Siklus II untuk memperbaiki siklus sebelumnya. Pada Siklus II diperoleh nilai rata-rata tes pemahaman konsep matematika sebesar 86,9 dengan ketuntasan klasikal sebesar 93,93\% dengan 31 peserta didik yang mencapai ketuntasan. Nilai rata-rata dan ketuntasan klasikal peserta didik sudah meningkat dan sesuai dengan harapan peneliti. Perbandingan nilai peserta didik disajikan dalam Tabel 1 berikut ini:

Tabel 1. Perbandingan Nilai Awal, Siklus I, dan Siklus II

\begin{tabular}{cccc}
\hline Keterangan & $\begin{array}{c}\text { Nilai } \\
\text { Awal }\end{array}$ & $\begin{array}{c}\text { Nilai } \\
\text { Siklus I }\end{array}$ & $\begin{array}{c}\text { Nilai } \\
\text { Siklus } \\
\text { II }\end{array}$ \\
\hline $\begin{array}{c}\text { Nilai rata- } \\
\text { rata }\end{array}$ & 56,3 & 78,6 & 86,9 \\
\hline $\begin{array}{c}\text { Peserta } \\
\text { didik yang } \\
\text { tuntas }\end{array}$ & $\begin{array}{c}\text { peserta } \\
\text { didik }\end{array}$ & $\begin{array}{c}\text { peserta } \\
\text { didik }\end{array}$ & $\begin{array}{c}\text { peserta } \\
\text { didik }\end{array}$ \\
\hline $\begin{array}{c}\text { Ketuntasan } \\
\text { klasikal }\end{array}$ & $12,12 \%$ & $72,72 \%$ & $93,93 \%$ \\
\hline $\begin{array}{c}\text { Jumlah } \\
\text { peserta } \\
\text { didik }\end{array}$ & \multicolumn{3}{c}{33 peserta didik } \\
\hline
\end{tabular}

Berdasarkan uraian di atas, dapat dikatakan bahwa proses pembelajaran dengan menggunakan model inkuiri terbimbing dapat meningkatkan pemahaman konsep matematika peserta didik.

Proses pembelajaran dengan menggunakan model inkuiri terbimbing 
pada materi segiempat dan segitiga tidak terlepas dari berbagai kendala dalam pelaksanaannya. Adapun kendala dalam penelitian dan solusi pemecahannya dapat dilihat pada Tabel 2 di bawah ini:

Tabel 2. Kendala Penelitian dan Solusi

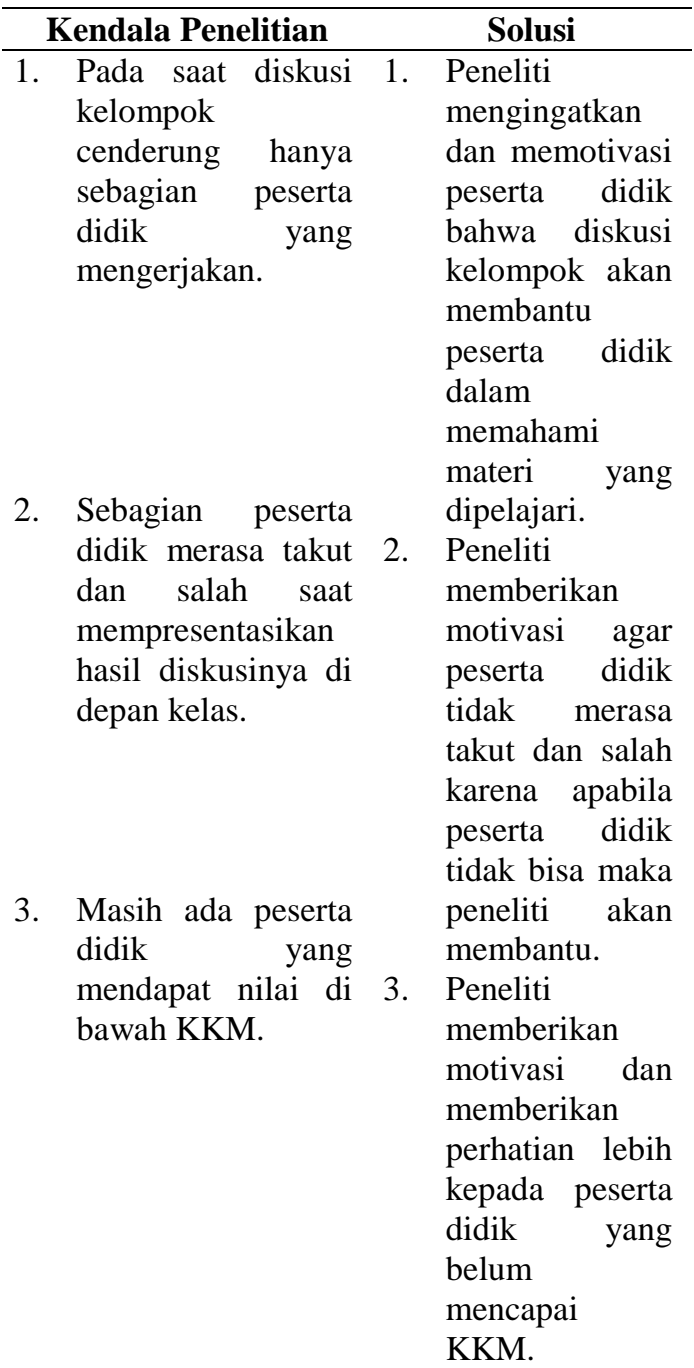

\section{PENUTUP}

Berdasarkan hasil penelitian yang telah dilakukan di SMP ISLAM SOERJO ALAM diperoleh kesimpulan: (1) penerapan model pembelajaran inkuiri terbimbing pada materi segiempat dan segitiga dapat terlaksana dengan baik sesuai dengan tahap-tahap pembelajaran inkuiri terbimbing. Hal ini terlihat dari keterlaksanaan pembelajaran kegiatan guru (peneliti) dan peserta didik pada setiap siklus mengalami peningkatan sebesar 90\% (kategori baik), kegiatan peserta didik sebesar 85\% (kategori baik) pada Siklus I dan pada Siklus II keterlaksanaan pembelajaran dilihat dari kegiatan guru meningkat menjadi 96,25\% (kategori baik), kegiatan peserta didik menjadi 93,75\% (kategori baik). (2) Penggunaan model pembelajaran inkuiri terbimbing pada materi segiempat dan segitiga dapat meningkatkan kemampuan pemahaman konsep matematika peserta didik kelas VII SMP ISLAM SOERJO ALAM. Kemampuan pemahaman konsep matematika peserta didik sebelum dilaksanakan tindakan sebesar 56,3 dengan ketuntasan klasikal sebesar $12,12 \%$, setelah dilaksanakan tindakan nilai rata-rata peserta didik meningkat menjadi 78,6 dengan ketuntasan klasikal sebesar $72,72 \%$ pada Siklus I, dan nilai rata-rata peserta didik meningkat menjadi 86,9 dengan ketuntasan klasikal sebesar 93,93\% pada Siklus II.

Beberapa saran yang dapat diberikan dari hasil penelitian antara lain: (1) hendaknya guru mencoba menerapkan model pembelajaran inkuiri terbimbing dalam menyampaikan pembelajaran matematika guna meningkatkan pemahaman konsep peserta didik, (2) bagi peneliti lainnya bisa mengembangkan model pembelajaran inkuiri terbimbing.

\section{DAFTAR RUJUKAN}

Anam, Khoirul. 2016. Pembelajaran Berbasis Inkuiri. Yogyakarta: Pustaka Pelajar.

Dian , S. 2014. Penerapan Pembelajaran Kooperatif Model Talking Stick untuk Meningkatkan Pemahaman Konsep Belajar Siswa Kelas VII-E SMP Negeri 2 Singosari pada Pokok Bahasan Himpunan. Disertai tidak diterbitkan. Malang: FKIP Universitas Kanjuruhan Malang. 
Gulo, W. 2008. Strategi Belajar Mengajar. Jakarta: Grasindo.

Kusumah, W., dan Dwitagama, D. 2012. Mengenal Penelitian Tindakan Kelas. Jakarta: PT Indeks.

Rostina, Sundayana. 2013. Media Pembelajaran Matematika. Bandung: Alfabeta.

Wardhani, Sri. 2008. Analisis SI dan SKL Mata Pelajaran Matematika SMP/MTs untuk Optimalisasi Tujuan Mata Pelajaran Matematika. Yogyakarta: Pusat
Pengembangan dan Pemberdayaan Pendidik dan Tenaga Kependidikan Matematika.

Watu, Fransiska. 2016. Penerapan Matematika dengan Pendekatan Saintifik untuk Meningkatkan Pemahaman Konsep dan Hasil Belajar Matematika Siswa Kelas VIIIA SMP NASIONAL Malang. Disertai tidak diterbitkan. Malang: FKIP Universitas Kanjuruhan Malang. 